\title{
Analysis of Genotoxic Damage in Different Diseases
}

\section{Gülşen GÖNEY ${ }^{1}$ iD Nurhan HALISDEMİR ${ }^{2}$}

${ }^{1}$ Süleyman Demirel University, Faculty of Pharmacy, Department of Toxicology, Isparta, Turkey, gulsengoney@sdu.edu.tr (Sorumlu Yazar/Corresponding Author)

${ }^{2}$ Firat University, Faculty of Arts and Sciences, Department of Statistics, Elazığ, Turkey, halisdemir@firat.edu.tr

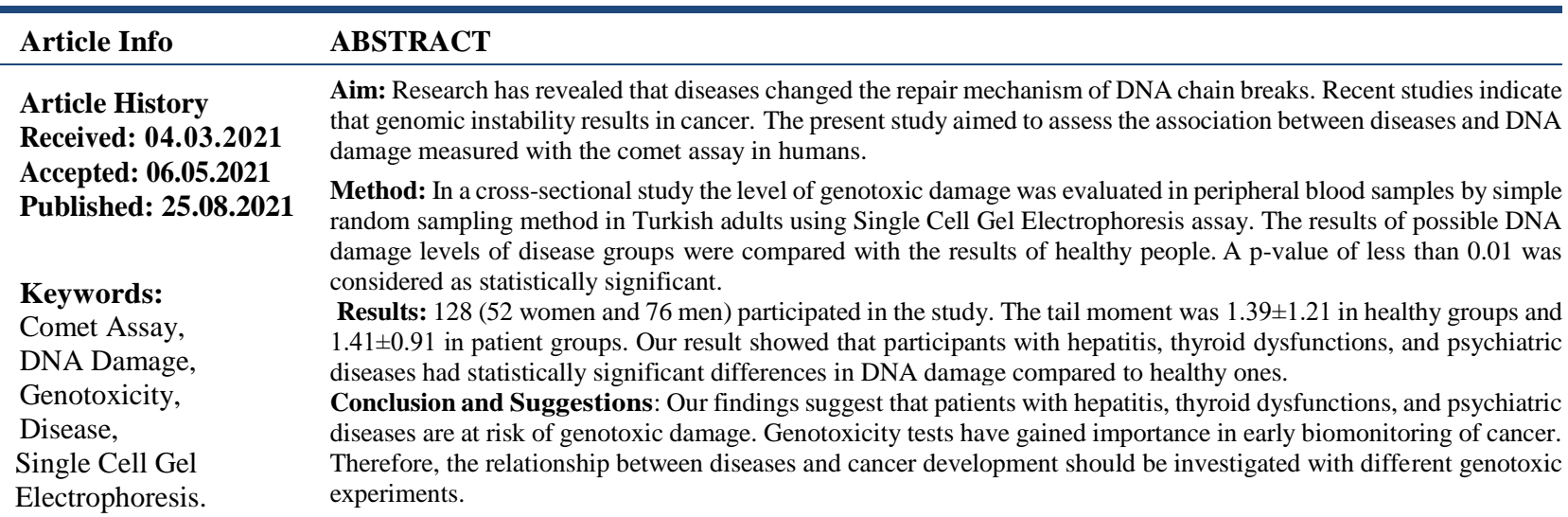

\section{Farklı Hastalıklarda Genotoksik Hasarın Analizi}

\begin{tabular}{|c|c|}
\hline Makale Bilgileri & ÖZ \\
\hline $\begin{array}{l}\text { Makale Geçmişi } \\
\text { Geliş: 04.03.2021 } \\
\text { Kabul: 06.05.2021 }\end{array}$ & $\begin{array}{l}\text { Amaç: Son yıllarda yapılmış olan araştırmalar ile hastalıkların DNA zincir kırıklarının onarım mekanizmasını } \\
\text { değiştirdiği ortaya çıartılmışır. Genomik kararsızlığın da kansere neden olduğu bilimsel çalışmalarla gösterilmiştir. } \\
\text { Sunulan çalışmada farklı hastalık gruplarındaki bireylerde olası genotoksik hasarın comet deneyi ile araştırılması } \\
\text { amaçlanmıştır. }\end{array}$ \\
\hline $\begin{array}{l}\text { Yayın: } 25.08 .2021 \\
\text { Anahtar Kelimeler: } \\
\text { Comet Deneyi, } \\
\text { DNA Hasarı, } \\
\text { Genotoksisite, } \\
\text { Hastalık, } \\
\text { Tek Hücre Jel } \\
\text { Elektroforezi. }\end{array}$ & $\begin{array}{l}\text { Yöntem: Sunulan kesitsel çalışmada } 18 \text { yaşından büyük kişilerin periferal kan örneklerinde olası DNA hasarı tek } \\
\text { hücre jel elektroforezi deneyi ile analiz edilmiştir. Farklı hastalık gruplarındaki kişilere ait olası DNA hasar düzeyi } \\
\text { sonuçları kontrol grubunu oluşturan sağlıklı kişilerin sonuçları ile karşılaştırılmıştır. p<0.01 değeri istatistiksel } \\
\text { anlamlılık düzeyi olarak kabul edilmiştir. } \\
\text { Bulgular: Sunulan araştırmaya } 52 \text { kadın, } 76 \text { erkek } 128 \text { gönüllü katılmıştır. Sağlılılı bireylerden oluşan kontrol } \\
\text { grubunda kuyruk momenti değeri } 1.39 \pm 1.21 \text { olarak tespit edilirken bu değer hastalığa sahip bireylerin oluşturduğu } \\
\text { grupta } 1.41 \pm 0.91 \text { olarak tespit edilmiştir. Hastalık ve kontrol grubunda kuyruk momenti değeri sonuçları } \\
\text { karş1laştırıldığında tiroid, hepatit ve psikiyatrik hastalık gruplarındaki kişilerde sonuçlara göre istatistiksel olarak } \\
\text { anlamlı fark bulunmuştur (p<0.01). } \\
\text { Sonuç ve Öneriler: Sonuçlarımız tiroid, hepatit ve psikiyatrik hastalıkların DNA hasarını etkileyebileceğini } \\
\text { göstermektedir. Genotoksisite testleri kanserin erken dönem biyoizlenmesinde oldukça önem kazanmıştır. Bu nedenle } \\
\text { farklı genotoksisite testleri ile de hastalıkların gelişimi ve kanser arasındaki ilişki araştırılmalıdır. }\end{array}$ \\
\hline
\end{tabular}

Atıf/Citation: Göney, G. \& Halisdemir, N. (2021). Analysis of genotoxic damage in different disease groups. Genel Sağlık Bilimleri Dergisi, 3(2), 124-132. 


\section{INTRODUCTION}

Recent studies indicate that genomic instability results in cancer. DNA damage may be associated with different diseases such as diabetes (Ibarra-Costilla et al., 2010; Moller et al., 2020), cardiovascular diseases (Demirbağ et al., 2005; Othmène et al., 2020), thyroid dysfunctions (Gerić, et al., 2016; Xu et al., 2021), stomach diseases (Poplawski et al., 2013; Sayed et al., 2020), asthma (Zeyrek et al., 2009; Hasbal et al., 2010; Gaballah et al., 2018), hepatitis (Horoz et al., 2006; Bolukbas et al., 2006; Mikhailov et al., 2017), musculoskeletal disorders (Esteves et al., 2017), and psychiatric diseases (Andreazza et al., 2007; Czarny et al., 2015). Previous studies putting forwarded that DNA damage are associated with diseases (Mohamed et al., 2017; Moller et al., 2020). Cellular parameters can in some cases detect early stages in the development of disease, or indicate risk of future disease (Collins et al., 2014). Measuring DNA damage, by genotoxicity tests, can be a marker of risk for cancer and other chronic diseases for an individual (Collins et al., 2014; Moller et al., 2020). The alkaline single-cell gel electrophoresis assay (comet assay) is the most important and widely used genotoxicity test in human biomonitoring studies (Milić et al., 2021). There is no study which gives information about the level of DNA damage in different disease groups in Turkish adults. The present study aimed to assess the association between DNA damage and diabetes, cardiovascular disease, thyroid dysfunction, stomach disease, asthma, hepatitis, musculoskeletal disorders, psychiatric diseases groups. For this purpose possible DNA damage levels measured with the comet assay. The levels of possible DNA damage in patients with compared with healthy controls to analysing genotoxic damage.

\section{METHOD}

\section{Research Design}

Present study, design as a cross-sectional study. A total of 128 volunteers aged 18 and over were included. We analyzed the correlation of diabetes, cardiovascular diseases, thyroid, stomach diseases, asthma, hepatitis, musculoskeletal disorders, and psychiatric diseases with DNA damage levels.

\section{Study Group}

This study was performed from April to December 2020 on 128 volunteers in Turkey. Among the volunteers who wanted to participate in the study, 64 patients and 64 control groups were selected by simple random sampling method. 52 females (40.6\%), and 76 males $(59.4 \%)$ who were $\geq 18$ $\left(M_{\text {age }}=33.6 \pm 10.8\right)$ were included. The blood samples were taken from each individual participating in the study into a heparine tubes. The correlation of diabetes, cardiovascular diseases, thyroid, stomach diseases, asthma, hepatitis, musculoskeletal disorders, and psychiatric diseases with DNA damage levels were analyzed.

\section{Research Instruments and Processes}

Alkaline Single Cell Gel Electrophoresis (Comet Assay): In this study, the possible damage level in DNA was analyzed with the Comet Assay. Alkaline Single Cell Gel Electrophoresis was applied according to the method of Tice et al. (2000). For detection of DNA damage, the values of DNA tail length $(\mu \mathrm{m})$, tail density (DNA\%), and tail moment parameters were recorded using the Comet Experiment Imaging Analysis System. All preparations were coded to reduce reader errors and were evaluated in a single-blind method. 


\section{Data Analysis}

The data were analyzed using the Statistical Package for Social Sciences (SPSS) version 21. Demographic characteristics of the participants were analyzed by calculating the mean and standard deviation (Std) values. A p-value of less than 0.01 was considered as statistically significant.

\section{Ethic}

This study was approved by Süleyman Demirel University Clinical Research Ethics Committee (dated 17.11.2020 and 367 decision number), A volunteer consent form was signed by each individual participating in the study.

\section{RESULTS}

128 volunteer $\left(M_{\mathrm{age}}=33.60 \pm 10.80\right) \geq 18$ ages were included in present study. Our analysis showed that $14.7 \%$ of participants had diabetes, $11.8 \%$ cardiovascular diseases, $7.4 \%$ thyroid, $14.7 \%$ stomach disease, $16.2 \%$ lung diseases, $8.8 \%$ hepatitis, $11.8 \%$ musculoskeletal disorders, and $7.4 \%$ psychiatric diseases. The demographic characteristics of study groups were shown in Table 1.

Table 1. Demographic Characteristics of Study Groups

\begin{tabular}{lcc}
\hline Study Groups & N & Percentage (\%) \\
Diabetes & 10 & 14.7 \\
Cardiovascular & 13 & 19.1 \\
Thyroid & 5 & 7.4 \\
Stomach Disease & 10 & 14.7 \\
Astma/COPD & 11 & 16.2 \\
Hepatitis & 6 & 8.8 \\
Musculoskeletal Disorders & 8 & 11.8 \\
Psychiatric Diseases & 5 & 7.4 \\
\hline
\end{tabular}

In this study, the genotoxic damage among patients and healthy groups were compared. The comet assay parameters of tail length $(\mu \mathrm{m})$, tail moment, and tail intensity (DNA\%) were shown in Table 2. The comet assay parameters of tail length $(\mu \mathrm{m})$, tail moment, and tail intensity (DNA\%) based on different age groups, gender, and smoking status of participants in two groups were compared and shown in Table 3.

Table 2. Comet Assay Results of Study Groups

\begin{tabular}{lccc}
\hline Parameters & Tail length & Tail moment & Tail intensity \\
Control & $29.1 \pm 4.41$ & $1.39 \pm 1.21$ & $5.72 \pm 2.10$ \\
Disease & $29.0 \pm 4.04$ & $1.41 \pm 0.91$ & $5.80 \pm 1.90$ \\
\hline
\end{tabular}

Table 3. The Comet Assay Results of Study Groups Based on Different Age Groups, Gender, and Smoking Status

\begin{tabular}{lcccccc}
\hline Variables & \multicolumn{2}{c}{ Tail length } & \multicolumn{2}{c}{ Tail moment } & \multicolumn{2}{c}{ Tail intensity } \\
& Control & Disease & Control & Disease & Control & Disease \\
\hline Age & & & & & & \\
$18-25$ & $28.9 \pm 2.92$ & $30.3 \pm 4.17$ & $1.28 \pm 0.57$ & $1.43 \pm 0.44$ & $6.44 \pm 1.66$ & $5.90 \pm 1.70$ \\
$26-33$ & $29.4 \pm 4.70$ & $30.2 \pm 4.62$ & $1.63 \pm 1.75$ & $1.30 \pm 0.50$ & $5.20 \pm 2.45$ & $5.52 \pm 2.05$ \\
$34-41$ & $29.3 \pm 6.87$ & $28.3 \pm 2.88$ & $1.06 \pm 0.39$ & $1.61 \pm 1.72$ & $4.99 \pm 1.70$ & $5.29 \pm 1.95$ \\
$41-49$ & $25.3 \pm 2.14$ & $28.4 \pm 4.38$ & $1.22 \pm 0.35$ & $1.40 \pm 0.46$ & $6.14 \pm 0.88$ & $6.39 \pm 1.84$ \\
$\geq 50$ & $33.1 \pm 4.99$ & $27.6 \pm 3.43$ & $1.30 \pm 0.33$ & $1.31 \pm 0.49$ & $6.53 \pm 3.55$ & $6.15 \pm 1.76$ \\
Gender & & & & & & \\
Female & $29.0 \pm 3.15$ & $29.2 \pm 4.34$ & $1.32 \pm 0.43$ & $1.50 \pm 0.59$ & $6.09 \pm 1.98$ & $6.45 \pm 2.58$ \\
\hline
\end{tabular}




\begin{tabular}{lllllll}
\hline Male & $29.2 \pm 5.85$ & $28.1 \pm 3.52$ & $1.50 \pm 1.84$ & $1.39 \pm 0.99$ & $5.18 \pm 2.18$ & $5.62 \pm 1.65$ \\
Smoking & & & & & & \\
No & $29.4 \pm 4.62$ & $28.9 \pm 3.77$ & $1.48 \pm 1.39$ & $1.62 \pm 1.25$ & $5.79 \pm 2.17$ & $5.95 \pm 1.77$ \\
Yes & $28.2 \pm 3.79$ & $29.1 \pm 4.29$ & $1.19 \pm 0.46$ & $1.26 \pm 0.51$ & $5.54 \pm 1.96$ & $5.69 \pm 2.02$ \\
\hline
\end{tabular}

The comet assay results of diabetes, cardiovascular diseases, thyroid dysfunctions, stomach diseases, hepatitis, asthma, chronic obstructive pulmonary disease (COPD), musculoskeletal disorders, and psychiatric diseases were shown in Table 4. Our result showed that there were statistically significant differences in the tail length amounts between psychiatric diseases (0.08), hepatitis $(0.08)$, and thyroid dysfunctions (0.07), and the healthy group. Also, there were statistically significant differences in the tail moment amounts between hepatitis (0.06), and thyroid dysfunctions (0.07), and healthy ones. Furthermore, there were statistically significant differences in the tail intensity results between psychiatric diseases (0.05), hepatitis (0.08), and thyroid dysfunctions (0.07), and the control group.

Table 4. Comet Assay Results of Disease Groups

\begin{tabular}{lccc}
\hline Diseases & Tail length & Tail moment & Tail intensity \\
Diabetes & $28.1 \pm 2.65$ & $1.41 \pm 0.48$ & $5.90 \pm 2.28$ \\
Cardiovascular Diseases & $30.9 \pm 5.29$ & $1.28 \pm 0.54$ & $5.28 \pm 2.19$ \\
Tyroid* & $28.6 \pm 2.70$ & $1.37 \pm 0.41$ & $6.32 \pm 1.24$ \\
Stomach Disease & $29.8 \pm 5.22$ & $1.45 \pm 0.42$ & $6.22 \pm 1.79$ \\
Hepatitis* & $27.1 \pm 1.66$ & $1.43 \pm 0.46$ & $6.20 \pm 1.87$ \\
Astma/COPD & $26.5 \pm 2.74$ & $1.13 \pm 0.43$ & $5.50 \pm 1.67$ \\
Musculoskeletal Disorders & $29.3 \pm 1.55$ & $1.41 \pm 0.68$ & $6.88 \pm 2.08$ \\
Psychiatric Diseases* & $31.6 \pm 6.07$ & $2.34 \pm 2.98$ & $4.05 \pm 1.72$ \\
\hline
\end{tabular}

*Psychiatric diseases $(\mathrm{p}=0.05)$, hepatitis $(\mathrm{p}=0.08)$, and thyroid dysfunctions $(\mathrm{p}=0.07)$.

The tail moment results of disease and control groups were shown in Figure 1. Also, comet parameters which include the tail length; tail moment; and tail intensity results of disease and control groups were shown in Figure 2.

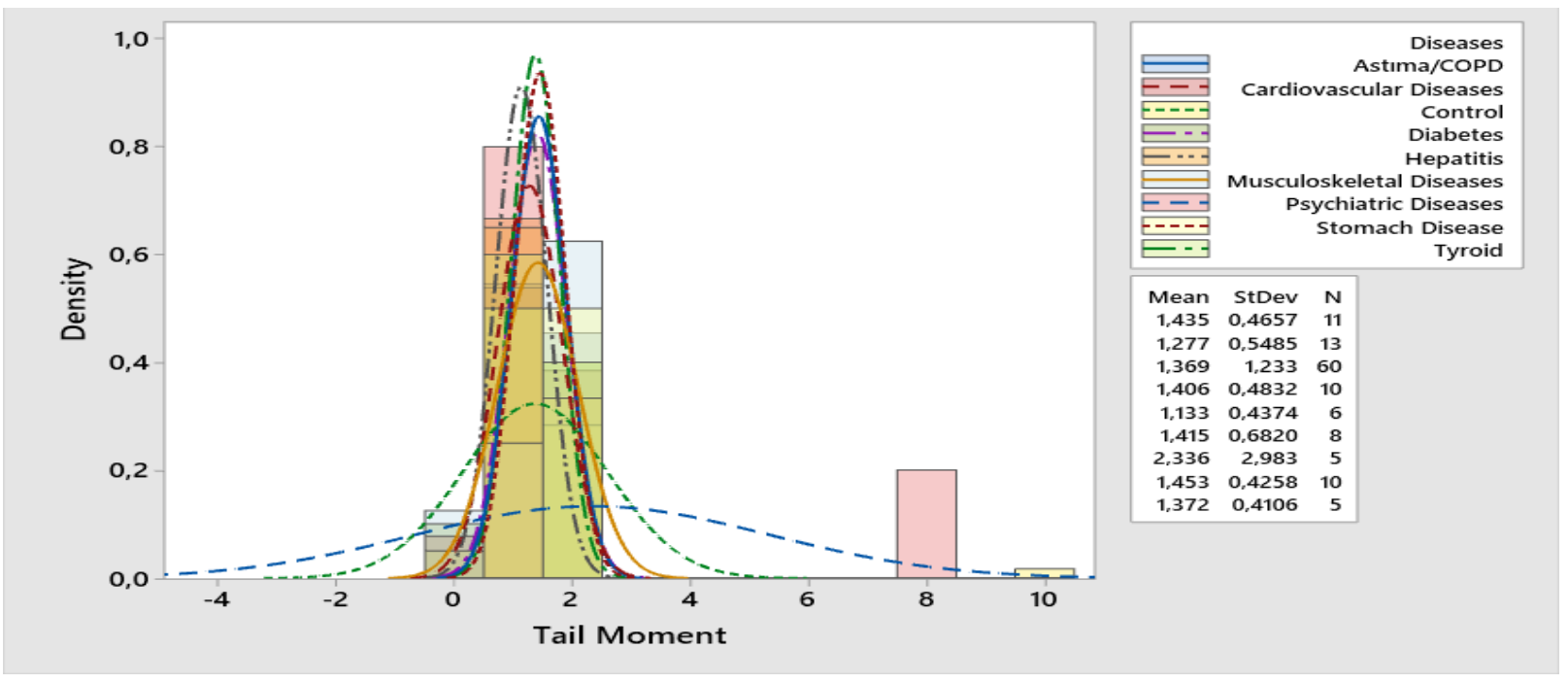

Figure 1. Tail moment values of study groups 


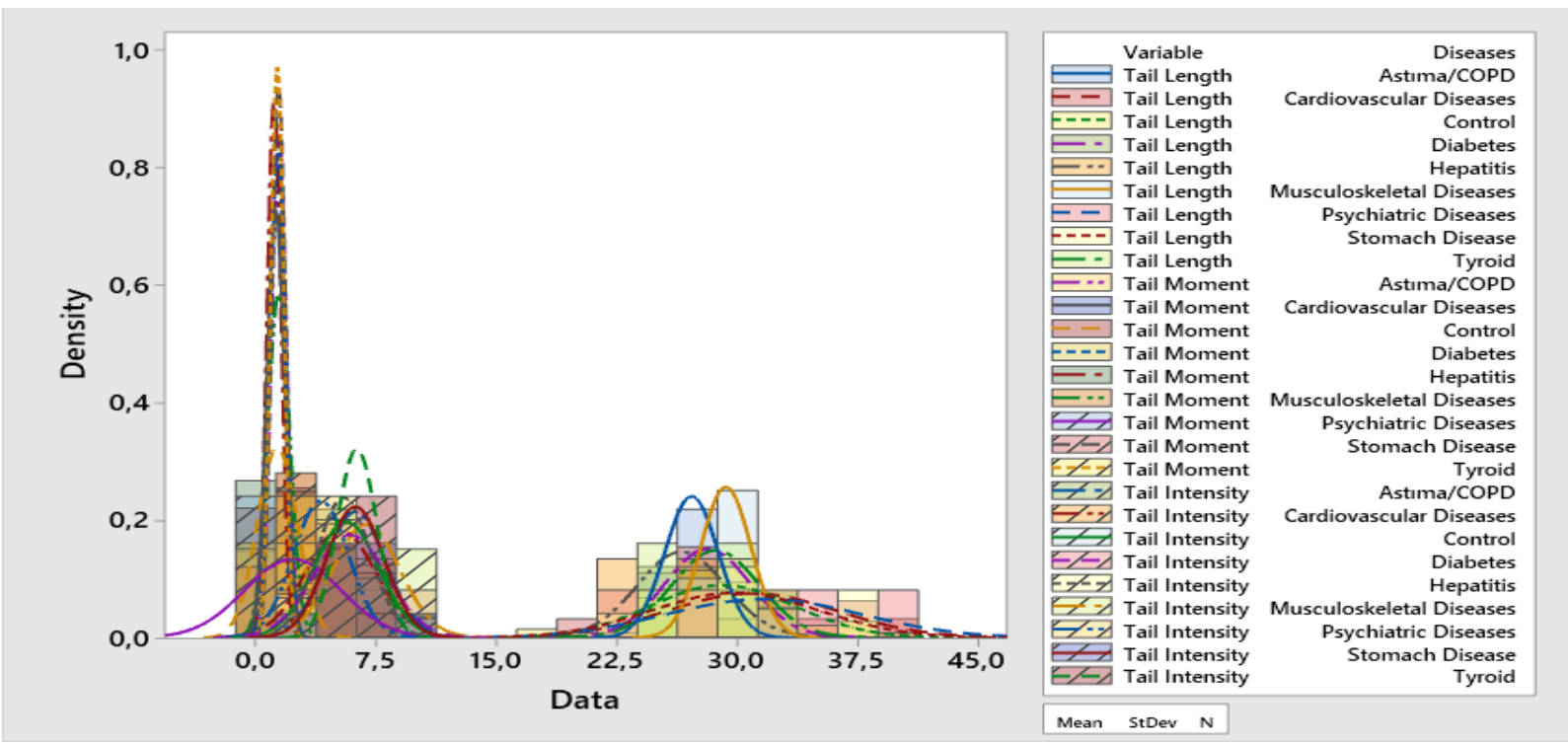

Figure 2. Tail length; tail moment; tail intensity values of study groups

\section{DISCUSSION}

In the present study, we purposed to investigate the possible genotoxic damage of different diseases using the comet assay that is one of the important genotoxicity experiments. In general, our result showed that participants with hepatitis $(\mathrm{p}=0.08)$, thyroid dysfunctions $(\mathrm{p}=0.07)$, and psychiatric diseases $(\mathrm{p}=0.05)$ had statistically significant differences in DNA damage compared to healthy ones. Many studies have examined the relationship between DNA damage and diseases in the scientific literature (Nelson \& Dizdaroglu, 2020; Jackson \& Bartek, 2009). DNA damage is one of the major reasons for cancer. Genotoxicity tests performed by measuring DNA damage are very important for early detection of cancer. Besides, genotoxicity test results have also been a risk consideration, usually in support of carcinogenicity assessments (Dearfield et al., 2002; Mohamed et al., 2017).

Our results showed that there was no significant difference in DNA damage in the type 2 diabetes mellitus and the control groups. One of our hypotheses was about diabetes patients. Similar to our results Ibarra-Costilla et al. (2010) evaluated DNA damage levels in 71 Mexican patients with type 2 diabetes mellitus using the comet assay. They found no significant differences in DNA damage in the study groups. Also, Mamur et al. (2016) compared comet assay parameters between diabetic and non-diabetic individuals. They found that diabetes mellitus patients were not statistically significantly affected by DNA damage. Besides, Pitozzi et al. (2003) showed no differences in the levels of DNA damage between the type 2 diabetes patients and healthy controls. Anderson et al. (1998) study analyzed DNA damage levels in diabetic patients using the comet assay. They indicated that DNA damage was at a lower than in the control.

Another hypothesis was about cardiovascular diseases. Our results showed that there was no significant difference in DNA damage in the cardiovascular diseases and the control groups. Demirbag et al. (2005) and Botto et al. (2002) evaluated the relationship between DNA damage and cardiovascular disease. According to their studies, DNA damage was significantly higher in coronary artery disease patients than in the control group $(p<0.001)$. Similarly, Bhat \& Gandhi (2017) showed that DNA damage in cardiovascular patients was significantly $(p<0.001)$ more than in the control group. They evaluated comet parameters and found that tail DNA percent was $22.45 \pm 0.50$ and tail moment was $89.35 \pm 3.16$.

Regarding thyroid dysfunctions, our analysis showed that there were significant differences between the amount of the tail length; tail moment; and tail intensity in thyroid dysfunctions patients 
and the healthy ones. As in our study, Geric et al. (2016) evaluated genome damage in patients with papillary thyroid cancer, follicular thyroid adenoma, and other thyroid diseases. They detected that the patients' group had higher comet assay tail intensity than control volunteers. However, Leprat et al. (1998) analyzed DNA damage using alkaline single-cell gel electrophoresis assay in patients with thyroid diseases. Their analysis showed no significant differences between patients and controls.

According to our results the relationship between DNA damage and psychiatric diseases were statistically significant. We found that the highest tail moment and tail length in psychiatric diseases. Psychiatric diseases can cause increased DNA damage (Ahmadimanesh, et al., 2019; Aleissa et al., 2019). Studies provide that evidence of high oxidative stress statuses and inadequate DNA repair capacities in patients with psychiatric diseases (Toprak et al., 2018; Panwar et al., 2020).

Finally, regarding hepatitis, our analysis showed that there were significant differences between the amount of the tail length; tail moment; and tail intensity in hepatitis patients and the healthy ones. Similarly, Fujita et al. (2008) showed that hepatic oxidative DNA damage is common in chronic viral hepatitis. Also, Mikhailov et al. (2017) evaluate DNA damage by comet assay. In hepatitis patients. They found a significant difference between DNA damage and patients with chronic viral hepatitis $\mathrm{C}$ and, B. In our study, the number of hepatitis patients was only six, so hepatitis type was not divided into subgroups such as $\mathrm{C}$ and $\mathrm{B}$. The low number of individuals in the groups due to the small number of volunteers participating in the study is among the limiting factors of our study.

\section{CONCLUSION}

Genotoxicity test is one of the methods used to evaluate DNA damage in an individual cell and is a widely used tool for monitoring genome stability in human diseases. DNA damage may play a role in the etiology of several degenerative diseases as well as cancers. Also, DNA damage is probably the most important fundamental cause of degenerative disease. Genotoxicity researches are important for biomonitoring of biological effect. In the present research, we aimed to evaluate the influence of DNA damage in patients with diabetes, cardiovascular disease, thyroid dysfunctions, stomach diseases, hepatitis, asthma, COPD, musculoskeletal disorders, and psychiatric diseases and compared them with healthy individuals in Turkey. Our result showed that participants with hepatitis, thyroid dysfunctions, and psychiatric diseases had statistically significant differences in DNA damage compared to healthy ones. Our findings suggest that patients with hepatitis, thyroid dysfunctions, and psychiatric diseases are at risk of genotoxic damage. Therefore, new studies with more participants aiming to investigate the relationship between genotoxic damage and diseases are needed. In fact, new studies should be conducted in which patients in each disease group will be followed up and whether there is cancer development or not.

Acknowledgments: The authors wish to thank all participants.

\section{Funding Sources}

No financial support was received in the study.

\section{Conflict of Interest}

The authors declare that are no conflict of interests.

\section{Author Contributions}

Design: G.G.; Data collection or processing: G.G., N.H.; Analysis or interpretation: N.H.;

Literature search: G.G.; Writing: G.G., N.H. 


\section{REFERENCES}

Ahmadimanesh, M., Abbaszadegan, M. R., Morshedi Rad, D., Moallem, S. A., Mohammadpour, A. H., Ghahremani, M. H., ... \& Etemad, L. (2019). Effects of selective serotonin reuptake inhibitors on DNA damage in patients with depression. Journal of Psychopharmacology, 33(11), 1364-1376. https://doi.org/10.1177/0269881119874461.

Aleissa, M., Sharp, S., Fiorentino, A., O'Brien, N., Bass, N., Curtis, D., \& McQuillin, A. (2019). Genetic association and functional characterization of a variant in the MCPH1 gene in bipolar disorder and schizophrenia. $\quad$ European Neuropsychopharmacology, 29, S966-S967. https://doi.org/10.1016/j.euroneuro.2017.08.330.

Anderson, D., Yu, T. W., Wright, J., \& Ioannides, C. (1998). An examination of DNA strand breakage in the comet assay and antioxidant capacity in diabetic patient. Mutation Research/Fundamental and Molecular Mechanisms of Mutagenesis, 398(1-2), 151-161. https://doi.org/10.1016/s0027-5107(97)00271-6.

Andreazza, A. C., Frey, B. N., Erdtmann, B., Salvador, M., Rombaldi, F., Santin, A., ... \& Kapczinski, F. (2007). DNA damage in bipolar disorder. Psychiatry Research, 153(1), 27-32. https://doi.org/10.1016/j.psychres.2006.03.025.

Bhat, M. A., \& Gandhi, G. (2017). Assessment of DNA damage in leukocytes of patients with coronary artery disease by comet assay. International Heart Journal, 58(2), 271-274. https://doi.org/10.1536/ihj.16-190.

Bolukbas, C., Bolukbas, F. F., Kocyigit, A., Aslan, M., Selek, S., Bitiren, M., \& Ulukanligil, M. (2006). Relationship between levels of DNA damage in lymphocytes and histopathological severity of chronic hepatitis $\mathrm{C}$ and various clinical forms of hepatitis B. Journal of Gastroenterology and Hepatology, 21(3), 610-616. https://doi.org/10.1111/j.1440-1746.2005.04069.x.

Botto, N., Masetti, S., Petrozzi, L., Vassalle, C., Manfredi, S., Biagini, A., \& Andreassi, M. G. (2002). Elevated levels of oxidative DNA damage in patients with coronary artery disease. Coronary Artery Disease, 13(5), 269-274. https://doi.org/10.1097/00019501-200208000-00004.

Collins, A., Koppen, G., Valdiglesias, V., Dusinska, M., Kruszewski, M., Møller, P., ... \& Bonassi, S. (2014). The comet assay as a tool for human biomonitoring studies: the ComNet Project. Mutation Research/Reviews in Mutation Research, 759, 27-39. https://doi.org/10.1016/j.mrrev.2013.10.001.

Czarny, P., Kwiatkowski, D., Kacperska, D., Kawczyńska, D., Talarowska, M., Orzechowska, A., ... \& Śliwiński, T. (2015). Elevated level of DNA damage and impaired repair of oxidative DNA damage in patients with recurrent depressive disorder. Medical Science Monitor, 6 (21), 412-8. https://doi.org/10.12659/MSM.892317.

Dearfield, K. L., Cimino, M. C., McCarroll, N. E., Mauer, I., \& Valcovic, L. R. (2002). Genotoxicity risk assessment: a proposed classification strategy. Mutation Research/Genetic Toxicology and Environmental Mutagenesis, 521(1-2), 121-135. https://doi.org/10.1016/s1383-5718(02)00236-X.

Demirbag, R., Yilmaz, R., \& Kocyigit, A. (2005). Relationship between DNA damage, total antioxidant capacity and coronary artery disease. Mutation Research/Fundamental and Molecular Mechanisms of Mutagenesis, 570(2), 197-203. https://doi.org/10.1016/j.mrfmmm.2004.11.003.

Esteves, F., Teixeira, E., Amorim, T., Costa, C., Pereira, C., Fraga, S., .. \& Costa, S. (2017). Assessment of DNA damage in a group of professional dancers during a 10-month dancing season. Journal of Toxicology and Environmental Health, Part A, 80(13-15), 797-804. https://doi.org/10.1080/15287394.2017.1331599.

Fujita, N., Sugimoto, R., Ma, N., Tanaka, H., Iwasa, M., Kobayashi, Y., ... \& Takei, Y. (2008). Comparison of hepatic oxidative DNA damage in patients with chronic hepatitis B and C. Journal of Viral Hepatitis, 15(7), 498-507. https://doi.org/10.1111/j.1365-2893.2008.00972.x.

Gaballah, H. H., Gaber, R. A., Sharshar, R. S., \& Elshweikh, S. A. (2018). NOD2 expression, DNA damage and oxido-inflammatory status in atopic bronchial asthma: Exploring their nexus to disease severity. Gene, 660, 128-135. https://doi.org/10.1016/j.gene.2018.03.061.

Gerić, M., Domijan, A. M., Gluščić, V., Janušić, R., Šarčević, B., \& Garaj-Vrhovac, V. (2016). Cytogenetic status and oxidative stress parameters in patients with thyroid diseases. Mutation Research/Genetic Toxicology and Environmental Mutagenesis, 810, 22-29. https://doi.org/10.1016/j.mrgentox.2016.09.010.

Hasbal, C., Aksu, B. Y., Himmetoglu, S., Dincer, Y., Koc, E. E., Hatipoglu, S., \& Akcay, T. (2010). DNA damage and glutathione level in children with asthma bronchiale: Effect of antiasthmatic therapy. Pediatric Allergy and Immunology, 21(4p2), e674-e678. https://doi.org/10.1111/j.1399-3038.2009.00959.x.

Horoz, M., Bolukbas, C., Bolukbas, F. F., Kocyigit, A., Aslan, M., Koylu, A. O., ... \& Koksal, M. (2006). Assessment of peripheral DNA damage by alkaline comet assay in maintenance hemodialysis subjects with hepatitis C infection. Mutation Research/Fundamental and Molecular Mechanisms of Mutagenesis, 596(1-2), 137-142. https://doi.org/10.1016/j.mrfmmm.2005.12.009. 
Ibarra-Costilla, E., Cerda-Flores, R. M., Dávila-Rodríguez, M. I., Samayo-Reyes, A., Calzado-Flores, C., \& Cortés-Gutiérrez, E. I. (2010). DNA damage evaluated by comet assay in Mexican patients with type 2 diabetes mellitus. Acta Diabetologica, 47(1), 111-116. https://doi.org/10.1007/s00592-009-0149-9.

Jackson, S. P., \& Bartek, J. (2009). The DNA-damage response in human biology and disease. Nature, 461(7267), 1071-1078. https://doi.org/10.1038/nature08467.

Leprat, F., Alapetite, C., Rosselli, F., Ridet, A., Schlumberger, M., Sarasin, A., \& Moustacchi, E. (1998). Impaired DNA repair as assessed by the "comet" assay in patients with thyroid tumors after a history of radiation therapy: A preliminary study. International Journal of Radiation Oncology Biology Physics, 40(5), 1019-1026. https://doi.org/ 10.1016/s0360-3016(97)00914-0.

Mamur, S., Unal, F., Altok, K., Deger, S. M., \& Yuzbasioglu, D. (2016). DNA damage in hemodialysis patients with chronic kidney disease; a test of the role of diabetes mellitus; a comet assay investigation. Mutation Research/Genetic Toxicology and Environmental Mutagenesis, 800, 22-27. https://doi.org/10.1016/j.mrgentox.2016.03.002.

Mikhailov, A. O., Popov, A. F., Ivanova, N. S., \& Simakova, A. I. (2017). The investigation of DNA damage in lymphocytes by comet assay in chronic viral hepatitis B patients. Epidemiology and Infectious Diseases, 22(2), 64-68. https://doi.org/10.22625/2072-6732-2017-9-2-29-36.

Milić, M., Ceppi, M., Bruzzone, M., Azqueta, A., Brunborg, G., Godschalk, R., ... \& Bonassi, S. (2021). The hCOMET project: International database comparison of results with the comet assay in human biomonitoring. Baseline frequency of DNA damage and effect of main confounders. Mutation Research/Reviews in Mutation Research, 108371 .

Mohamed, S. A. K. S., Upreti, S., Rajendra, S. V., \& Dang, R. (2017). Genotoxicity: Mechanisms, testing guidelines and methods. Global Journal of Pharmacy \& Pharmaceutical Sciences, 1(5), 133-138. https://doi: 10.19080/GJPPS.2017.01.555575.

Møller, P., Stopper, H., \& Collins, A. R. (2020). Measurement of DNA damage with the comet assay in highprevalence diseases: current status and future directions. Mutagenesis, 35(1), 5-18. https://doi.org/10.1093/mutage/gez018.

Nelson, B. C., \& Dizdaroglu, M. (2020). Implications of DNA damage and DNA repair on human diseases. Mutagenesis, 35(1), 1-3. https://doi.org/10.1093/mutage/gez048.

Othmène, Y. B., Monceaux, K., Karoui, A., Salem, I. B., Belhadef, A., Abid-Essefi, S., \& Lemaire, C. (2020). Tebuconazole induces ROS-dependent cardiac cell toxicity by activating DNA damage and mitochondrial apoptotic pathway. Ecotoxicology and Environmental Safety, 204, 111040. https://doi.org/10.1016/j.ecoenv.2020.111040.

Panwar, R., Sivakumar, M., Menon, V., \& Vairappan, B. (2020). Changes in the levels of comet parameters before and after fluoxetine therapy in major depression patients. Anatomy \& Cell Biology, 53(2), 194. https://doi.org/10.5115/acb.19.217.

Pitozzi, V., Giovannelli, L., Bardini, G., Rotella, C. M., \& Dolara, P. (2003). Oxidative DNA damage in peripheral blood cells in type 2 diabetes mellitus: Higher vulnerability of polymorphonuclear leukocytes. Mutation Research/Fundamental and Molecular Mechanisms of Mutagenesis, 529(1-2), 129-133. https://doi.org/10.1016/s0027-5107(03)00114-3.

Poplawski, T., Chojnacki, C., Czubatka, A., Klupinska, G., Chojnacki, J., \& Blasiak, J. (2013). Helicobacter pylori infection and antioxidants can modulate the genotoxic effects of heterocyclic amines in gastric mucosa cells. Molecular biology reports, 40(8), 5205-5212. https://doi.org/10.1007/s11033-013-2622-3.

Sayed, I. M., Sahan, A. Z., Venkova, T., Chakraborty, A., Mukhopadhyay, D., Bimczok, D., ... \& Das, S. (2020). Helicobacter pylori infection downregulates the DNA glycosylase NEIL2, resulting in increased genome damage and inflammation in gastric epithelial cells. Journal of Biological Chemistry, 295(32), 11082-11098. https://doi.org/10.1074/jbc.RA119.009981.

Tice, R. R., Agurell, E., Anderson, D., Burlinson, B., Hartmann, A., Kobayashi, H., ... \& Sasaki, Y. F. (2000). Single cell gel/comet assay: guidelines for in vitro and in vivo genetic toxicology testing. Environmental and Molecular Mutagenesis, 35(3), 206-221. https://doi.org/10.1002/(sici)1098-2280(2000)35:3<206::aidem8>3.0.co;2-j.

Topak, O. Z., Ozdel, O., Dodurga, Y., \& Secme, M. (2018). An evaluation of the differences in DNA damage in lymphocytes and repair efficiencies in patients with schizophrenia and schizoaffective disorder. Schizophrenia Research, 202, 99-105. https://doi.org/10.1016/j.schres.2018.06.052.

Xu, Q., Mackay, R. P., Xiao, A. Y., Copland, J. A., \& Weinberger, P. M. (2021). Ym155 Induces oxidative stressmediated DNA damage and cell cycle arrest, and causes programmed cell death in anaplastic thyroid cancer cells. International Journal of Molecular Sciences, 22(4), 1961. https://doi.org/10.3390/ijms22041961. 
Zeyrek, D., Cakmak, A., Atas, A., Kocyigit, A., \& Erel, O. (2009). DNA damage in children with asthma bronchiale and its association with oxidative and antioxidative measurements. Pediatric Allergy and Immunology, 20(4), 370-376. https://doi.org/10.1111/j.1399-3038.2008.00780.x. 